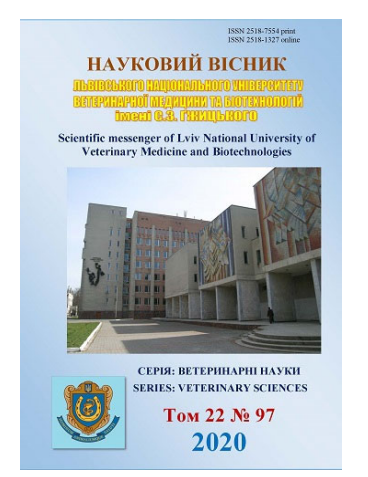

Науковий вісник Дьвівського національного університету ветеринарної медицини та біотехнологій імені С.3. Гжицького.

$$
\text { Серія: Ветеринарні науки }
$$

Scientific Messenger of Lviv National University of Veterinary Medicine and Biotechnologies. Series: Veterinary sciences doi: $10.32718 /$ nvlvet9710

https://nvlvet.com.ua/index.php/journal

UDC 619:581.4:636.084.7:619:615.9:577.1

\title{
Effect of sodium selenite and feed additive "Metisevit plus" on morphological parameters of blood of rats at the intoxication of Cadmium and Lead
}

\author{
S. O. Slobodian ${ }^{1}$, B. V. Gutyj ${ }^{1}$, S. D. Murska ${ }^{2}$ \\ ${ }^{1}$ Stepan Gzhytskyi National University of Veterinary Medicine and Biotechnologies Lviv, Ukraine \\ ${ }^{2}$ State Scientific-Research Control Institute of Veterenary Medicinal Products and Feed Additives, Lviv, Ukraine
}

Article info

Received 28.01.2020 Received in revised form 27.02.2020 Accepted 28.02.2020

Stepan Gzhytskyi National University of Veterinary Medicine and Biotechnologies Lviv, Pekarska Str., 50, Lviv, 79010, Ukraine. Tel.: +38-067-316-74-30 E-mail: solomiaslobodian@ukr.net

State Scientific-Research Control Institute of Veterenary Medicinal Products and Feed Additives, Donetska Str., 11, Lviv, 79019, Ukraine.

\begin{abstract}
Slobodian, S. O., Gutyj, B. V., \& Murska, S. D. (2020). Effect of sodium selenite and feed additive "Metisevit plus" on morphological parameters of blood of rats at the intoxication of Cadmium and Lead. Scientific Messenger of Lviv National University of Veterinary Medicine and Biotechnologies. Series: Veterinary sciences, 22(97), 52-57. doi: 10.32718/nvlvet9710
\end{abstract}

Heavy metals, Lead and Cadmium, are hazardous environmental pollutants. In the body of mammals, Cadmium and Lead have a toxic effect on a number of organs and systems. The mechanism of action of these poisons is to inhibit the activity of enzyme systems by blocking carboxyl, amine and SH groups of protein molecules. The aim of the study was to investigate the effect of sodium selenite and feed additive "Metisevit plus" on the morphological parameters of rat blood by Cadmium and Lead intoxication. The experiments were carried out on 200-220 g male Wistar rats, out of which 3 groups of animals were formed: a control and two experimental animals. Rats in the control and experimental groups were administered $16.6 \%$ aqueous lead acetate at a dose of $100 \mathrm{mg} / \mathrm{kg}$ and $0.029 \%$ aqueous cadmium chloride at a dose of $2.0 \mathrm{mg} / \mathrm{kg}$. The rats of the first experimental group additionally used sodium selenite. The rats of the second experimental group additionally used the feed additive "Metisevit plus". Lead-cadmium loading in rats was accompanied by erythrocytopenia and leukopenia. The lowest erythrocyte count was in the blood of diseased rats at 21 days, where it decreased by $41.3 \%$, respectively, compared to the initial values. It was found that hemoglobin level decreased to $90.3 \pm 2.63 \mathrm{~g} / \mathrm{l}$ during Cadmium and Lead intoxication in control rats. At the same time as the decrease in hemoglobin level and the number of erythrocytes in intoxicated rats, an increase in the average hemoglobin content in one erythrocyte of blood was observed up to $20.57 \pm 1.20 \mathrm{pg}$ As a result of the development of lead-cadmium intoxication in ill rats, leukopenia was noted, which, in our opinion, is associated with systemic lesions of cadmium and lead in the blood-forming organs of animals that suppress leukopoiesis. It was found that the number of leukocytes in patients of rats of group $C$ decreased by $36.1 \%$ compared with the initial data. The use of sodium selenite and the feed additive "Metisevit plus" in rats under lead-cadmium loading contributed to the increase in the number of red blood cells and hemoglobin level, as well as the decrease in the number of leukocytes in their blood. The improvement of normalizing effect on the morphological parameters of blood of rats under conditions of loading with heavy metals was shown by the feed additive "Metisevit plus" in comparison with sodium selenite.

Key words: toxicology, Cadmium, Lead, sodium selenite, feed additive "Metisevit plus".

\section{Вплив селеніту натрію i кормової добавки “Метісевіт плюс" на морфологічні показники крові щурів за інтоксикації Кадмісм і Свинцем}

\author{
С. О. Слободян ${ }^{1}$, Б. В. Гутий ${ }^{1}$, С. Д. Мурська ${ }^{2}$ \\ ${ }^{1}$ Львівський національний університет ветеринарної медицини та біотехнологій імені С. 3. Гжсицького, \\ м. Львів, Україна
}


${ }^{2}$ Державний науково-дослідний контрольний інститут ветеринарних препаратів та кормових добавок, м. Львів, Украӥна

Важкі метали, Свинець і Кадмій, відносяться до небезпечних забруднювачів довкілля. В організмі ссавців вони проявляють токсичний вплив на низку органів і систем. Механізм дї даних токсикантів призводить до пригнічення активності ензимних систем. Результатом того є блокування карбоксильних, амінних та SH-груп білкових молекул. Метою цієї роботи було дослідити вплив селеніту натрію і кормової добавки “Метісевіт плюс” на морфологічні показники крові шурів за інтоксикації Кадмієм і Свинцем. Досліди проводились на щурах-самиях лінї “Вістар”, масою 200-220 г, з яких було сформовано 3 групи тварин: контрольну та дві дослідні. Щурам контрольної та дослідних груп вводили 16,6\% водний розчин ацетату свинцю в дозі 100 мг/кг і 0,029 \% водний розчин кадмію хлориду в дозі 2,0 мг/кг. Щурам першої дослідної групи додатково застосовували селеніт натрію. Щурам другої дослідної групи додатково застосовували кормову добавку “Метісевіт плюс”. Свинцево-кадмієве навантаження у шурів супроводжувалося еритроцитопенією та лейкопенією. Найнижчою кількість еритроцитів була у крові хворих щурів на 21 добу, де порівняно з початковими величинами вона знизилася на 41,3 \% відповідно. Встановлено, щуо за інтоксикації Кадмієм і Свинцем у щурів контрольної групи рівень гемоглобіну знизився до 90,3 \pm 2,63 г/л. Одночасно із зниженням рівня гемоглобіну та кількості еритроцитів у інтоксикованих шурів відзначали збільшення середнього вмісту гемоглобіну в одному еритроциті крові до $20,57 \pm 1,20$ пг. $У$ результаті розвитку свинцево-кадмієвої інтоксикації у хворих щурів відзначають лейкопенію, яка, на нашу думку, пов'язана із системним ураженням Кадмієм і Свинцем кровотворних органів тварин, які пригнічують лейкопоез. Встановлено, ияо кількість лейкоцитів у хворих щурів контрольної групи знизилася на 36,1\% порівняно з початковими даними. Застосування селеніту натрію та кормової добавки "Метісевіт плюс" цурам за умов свинщево-кадмієвого навантаження сприяли підвищенню кількості еритроцитів і рівня гемоглобіну, а також зниженню кількості лейкоцитів у їх крові. Кращу дію з нормалізації на морфологічні показники крові щурів за умов навантаження вищезгаданими важкими металами проявляла кормова добавка “Метісевіт плюс" порівняно із селенітом натрію.

\section{Вступ}

Останніми роками велика увага приділяється вивченню впливу шкідливих факторів навколишнього середовища на продуктивність тварин (Lavryshyn et al., 2018; Gutyi et al., 2019). Серед шкідливих екзогенних факторів, що негативно впливають на організм тварин, за даними багатьох дослідників негативну роль відіграють важкі метали як пріоритетні забруднювачі навколишнього середовища (Gutyi et al., 2018; Ostapyuk \& Gutyj, 2019). Наявність важких металів у біосфері (воді, грунті, рослинах) має подвійне значення: як мікроелементи вони необхідні для нормального перебігу фізіологічних процесів, але водночас токсичні у підвищених концентраціях, що негативно позначається на здоров'ї, продуктивності тварин та якості сільськогосподарської продукції (Sachko et al., 2016; Lavryshyn \& Gutyj, 2019).

Токсичність металів для організму людей і тварин залежить від багатьох факторів: шляху проникнення, тропності до певних органів, тканини чи системи, загальної дози металу та від того, чи одноразовим або хронічним було отруєння (Rodríguez et al., 2001; Marushko et al., 2010; Myslyva, 2013; Stepanchuk, 2014; Petrynych et al., 2017). Крім цього, відповідь на дію токсиканту залежить від виду, віку, статі тварини та загального стану організму у цей момент (Salvatori et al., 2004; El-Shahat et al., 2009; Kuras \& Ersteniuk, 2019).

Результати багатьох експериментальних робіт вказують на те, що в організмі ссавців Кадмій і Свинець проявляють токсичний вплив на низку органів і систем (Al-Azemi et al., 2010; Lavryshyn et al., 2019). Тривалий контакт з даними металами та їх надходження в організм, навіть у малих концентраціях, призводить до пригнічення імунітету, зниження опору інфекціям, розвитку алергічної, автоімунної та онкологічної патології (Ali et al., 1986).
Згідно даних літератури відомо, що для попередження негативної дії важких металів використовують препарати на основі Селену. Механізм захисної дії Селену обумовлений його взаємодією 3 солями важких металів 3 наступним утворенням біологічно неактивних селенідів (Uetani et al., 2005; Hutyi, 2013; Hutyi, 2015; Nazaruk et al., 2015; Ostapyuk \& Gutyj, 2018).

Саме тому метою роботи було дослідити вплив селеніту натрію і кормової добавки "Метісевіт плюс" на морфологічні показники крові щурів за інтоксикації Кадмієм і Свинцем.

\section{Матеріал і методи досліджень}

Досліди проводились на щурах-самцях лінії "Вістар”, масою 200-220 г, 3 яких було сформовано 3 групи тварин: контрольну та дві дослідні. Щурам контрольної та дослідних груп вводили 16,6 \% водний розчин ацетату свинцю в дозі 100 мг/кг і 0,029 \% водний розчин кадмію хлориду в дозі 2,0 мг/кг. Щурам першої дослідної групи (Д 1 ) додатково застосовували селеніт натрію у дозі 0,2 мг/кг маси тіла. Щурам другої дослідної групи додатково застосовували кормову добавку "Метісевіт плюс" у дозі 0,5 мг/кг маси тіла (Hutyi et al., 2019).

Упродовж усього експерименту щурів утримували на збалансованому раціоні, що був збалансований за усіма необхідними компоненти, питну воду тварини отримували без обмежень із скляних поїлок об'ємом 0,2 літра.

Усі маніпуляції з тваринами проводили відповідно до Європейської конвенції про захист хребетних тварин, які використовуються для експериментальних і наукових цілей (Страсбург, 1986 р.).

Кров для гематологічних досліджень забирали під ефірним наркозом з яремної вени на 1, 7, 14, 21 та 28 доби досліду. В стабілізованій крові визначали: вміст 
гемоглобіну, кількість еритроцитів і лейкоцитів, індекси червоної крові - за допомогою гематологічного аналізатора Mythic-18.

Аналіз результатів досліджень проводили за допомогою пакету програм Statistica 6.0. Вірогідність різниць оцінювали за t-критерієм Стьюдента. Результати вважали вірогідними при $\mathrm{P} \leq 0,05$.

\section{Результати та їх обговорення}

При інтоксикації важкими металами у щурів кількість еритроцитів упродовж усього досліду знижувалася. Найнижчою кількість еритроцитів була у крові щурів групи К на 21 добу, де порівняно з початковими величинами вона знизилася на 41,3 \% відповідно (табл. 1).

\section{Таблиця 1}

Вплив селеніту натрію та кормової добавки “Метісевіт плюс" на кількість еритроцитів у крові щурів за інтоксикації Кадмієм і Свинцем, Т/л $(\mathrm{M} \pm \mathrm{m}, \mathrm{n}=6)$

\begin{tabular}{|c|c|c|c|c|c|}
\hline \multirow{2}{*}{ Групи тварин } & \multirow{2}{*}{ Початкові дані } & \multicolumn{4}{|c|}{ Доба експерименту } \\
\hline & & 7 & 14 & 21 & 28 \\
\hline $\begin{array}{l}\text { Контрольна } \\
\left(\mathrm{Cd}^{2+}+\mathrm{Pb}^{2+}\right)\end{array}$ & $7,48 \pm 0,08$ & $6,51 \pm 0,11$ & $5,23 \pm 0,09$ & $4,39 \pm 0,16$ & $4,41 \pm 0,22$ \\
\hline $\begin{array}{l}\text { Дослідна } 1 \\
\left(\mathrm{Cd}^{2+}+\mathrm{Pb}^{2+}+\text { селеніт натрію) }\right.\end{array}$ & $7,39 \pm 0,05$ & $6,84 \pm 0,15$ & $6,56 \pm 0,18^{* * *}$ & $6,28 \pm 0,09^{* * *}$ & $6,70 \pm 0,21 * * *$ \\
\hline $\begin{array}{l}\text { Дослідна } 2 \\
\left(\mathrm{Cd}^{2+}+\mathrm{Pb}^{2+}+\text { Метісевіт плюс }\right)\end{array}$ & $7,43 \pm 0,10$ & $7,15 \pm 0,20^{*}$ & $6,99 \pm 0,17 * * *$ & $6,73 \pm 0,20 * * *$ & $7,40 \pm 0,15^{* * *}$ \\
\hline
\end{tabular}

Після застосування щурам першої дослідної групи селеніту натрію у дозі 0,2 мг/кг маси тіла кількість еритроцитів на 7 добу досліду відносно початкових величин знизилася до $6,84 \pm 0,15$ Т/л, однак порівняно 3 хворими щурами даний показник був вищим на $5,1 \%$. Пізніше кількість еритроцитів у крові першої дослідної групи на 14 і 21 добу досліду була вищою на 25,4 і 43,1 \% відносно показників контрольної групи. Однак слід зауважити, що кількість еритроцитів у крові дослідної групи щурів, яким застосовували селеніт натрію не досягала початкових величин, взятих до початку навантаження важкими металами.

Застосування щурам другої дослідної групи кормової добавки "Метісевіт плюс" сприяло нормалізації кількості еритроцитів на 21 і 28 добу досліду, де відповідно даний показник був вищим на 53,3 і 67,8 \% відносно контрольної групи.

Встановлено, що за інтоксикації Кадмієм і Свинцем у щурів групи К рівень гемоглобіну знизився до $90,3 \pm 2,63$ г/л. Після введення селеніту натрію та кормової добавки “Метісевіт плюс” щурам з проявами інтоксикації встановлено підвищення рівня гемоглобіну на 7 і 14 доби досліду на 1,1 і 6,8 \% відносно показників крові щурів групи К. На 21 добу досліду застосування кормової добавки щурам другої дослідної групи сприяло вірогіднішому збільшенню рівня гемоглобіну чим застосування селеніту натрію (табл. 2).

\section{Таблиця 2}

Вплив селеніту натрію та кормової добавки "Метісевіт плюс" на рівень гемоглобіну в крові щурів за інтоксикації Кадмієм і Свинцем, г/л $(\mathrm{M} \pm \mathrm{m}, \mathrm{n}=6)$

\begin{tabular}{|c|c|c|c|c|c|}
\hline \multirow{2}{*}{ Групи тварин } & \multirow{2}{*}{ Початкові дані } & \multicolumn{4}{|c|}{ Доба експерименту } \\
\hline & & 7 & 14 & 21 & 28 \\
\hline $\begin{array}{l}\text { Контрольна } \\
\left(\mathrm{Cd}^{2+}+\mathrm{Pb}^{2+}\right)\end{array}$ & $118,9 \pm 2,57$ & $103,4 \pm 1,58$ & $95,7 \pm 4,03$ & $90,3 \pm 2,63$ & $95,4 \pm 1,84$ \\
\hline $\begin{array}{l}\text { Дослідна } 1 \\
\left(\mathrm{Cd}^{2+}+\mathrm{Pb}^{2+}+\text { селеніт натрію) }\right.\end{array}$ & $117,5 \pm 0,99$ & $104,5 \pm 2,10$ & $102,7 \pm 3,36$ & $101,4 \pm 1,84^{* *}$ & $110,4 \pm 4,05^{* *}$ \\
\hline $\begin{array}{l}\text { Дослідна } 2 \\
\left(\mathrm{Cd}^{2+}+\mathrm{Pb}^{2+}+\text { Метісевіт плюс }\right)\end{array}$ & $115,1 \pm 1,99$ & $110,4 \pm 3,57$ & $115,2 \pm 2,43^{* *}$ & $120,3 \pm 3,12 * * *$ & $126,1 \pm 2,49 * * *$ \\
\hline
\end{tabular}

Так, рівень гемоглобіну у крові щурів другої дослідної групи у вказаний період експерименту зріс на $33,2 \%$, тоді як у першої - на 12,3 \% Найвищим рівень гемоглобіну у крові щурів був на 28 добу досліду у другої дослідної групи, яким за інтоксикації важкими металами застосовували кормову добавку "Метісевіт плюс".

Одночасно із зниженням рівня гемоглобіну та кількості еритроцитів у щурів в яких проявлялась інтоксикація відзначали збільшення середнього вмісту гемоглобіну в одному еритроциті крові до 20,57 $\pm 1,20$ пг (табл. 3).

Застосування селеніту натрію та кормової добавки щурам дослідних груп, яким здійснювали навантаження Кадмієм і Свинцем, встановлено зниження середнього вмісту гемоглобіну в одному еритроциті на 21 добу досліду на 21,5 і 13,1 \% відносно контрольної групи щурів.

У результаті розвитку свинцево-кадмієвої інтоксикації у хворих щурів відзначають лейкопенію, яка, на нашу думку, пов'язана із системним ураженням Кад- 
мієм і Свинцем кровотворних органів тварин, які пригнічують лейкопоез. Встановлено, що кількість лейкоцитів у хворих щурів групи К знизилася на
36,1 \% порівняно 3 початковими даними, ще до початку навантаження важкими металами (табл. 4).

\section{Таблиця 3}

Вплив селеніту натрію та кормової добавки “Метісевіт плюс" на середній вміст гемоглобіну в одному еритроциті крові щурів за інтоксикації Кадмієм і Свинцем, пг $(\mathrm{M} \pm \mathrm{m}, \mathrm{n}=6)$

\begin{tabular}{|c|c|c|c|c|c|}
\hline \multirow{2}{*}{ Групи тварин } & \multirow{2}{*}{ Початкові дані } & \multicolumn{4}{|c|}{ Доба експерименту } \\
\hline & & 7 & 14 & 21 & 28 \\
\hline $\begin{array}{l}\text { Контрольна } \\
\left(\mathrm{Cd}^{2+}+\mathrm{Pb}^{2+}\right)\end{array}$ & $15,89 \pm 1,33$ & $15,88 \pm 1,12$ & $18,30 \pm 1,35$ & $20,57 \pm 1,20$ & $21,63 \pm 1,29$ \\
\hline $\begin{array}{l}\text { Дослідна } 1 \\
\left(\mathrm{Cd}^{2+}+\mathrm{Pb}^{2+}+\text { селеніт натрію) }\right.\end{array}$ & $15,90 \pm 1,06$ & $15,28 \pm 1,25$ & $15,66 \pm 0,99$ & $16,15 \pm 1,32 *$ & $16,48 \pm 1,21^{*}$ \\
\hline $\begin{array}{l}\text { Дослідна } 2 \\
\left(\mathrm{Cd}^{2+}+\mathrm{Pb}^{2+}+\text { Mетісевіт плюс }\right)\end{array}$ & $15,49 \pm 1,22$ & $15,44 \pm 1,30$ & $16,48 \pm 1,08$ & $17,88 \pm 1,30$ & $17,04 \pm 1,09$ \\
\hline
\end{tabular}

\section{Таблиця 4}

Вплив селеніту натрію та кормової добавки “Метісевіт плюс" на кількість лейкоцитів у крові щурів за інтоксикації Кадмієм і Свинцем, Г/л $(\mathrm{M} \pm \mathrm{m}, \mathrm{n}=6)$

\begin{tabular}{|c|c|c|c|c|c|}
\hline \multirow{2}{*}{ Групи тварин } & \multirow{2}{*}{ Початкові дані } & \multicolumn{4}{|c|}{ доба експерименту } \\
\hline & & 7 & 14 & 21 & 28 \\
\hline $\begin{array}{l}\text { Контрольна } 1 \\
\left(\mathrm{Cd}^{2+}+\mathrm{Pb}^{2+}\right)\end{array}$ & $8,12 \pm 0,75$ & $7,63 \pm 0,82$ & $6,42 \pm 0,55$ & $5,19 \pm 0,85$ & $5,30 \pm 1,00$ \\
\hline $\begin{array}{l}\text { Дослідна } 1 \\
\left(\mathrm{Cd}^{2+}+\mathrm{Pb}^{2+}+\text { селеніт натрію) }\right.\end{array}$ & $7,85 \pm 0,56$ & $7,71 \pm 0,37$ & $7,32 \pm 0,46$ & $7,02 \pm 0,56$ & $7,10 \pm 0,51$ \\
\hline $\begin{array}{l}\text { Дослідна } 2 \\
\left(\mathrm{Cd}^{2+}+\mathrm{Pb}^{2+}+\text { Метісевіт плюс }\right)\end{array}$ & $7,92 \pm 0,81$ & $7,74 \pm 0,71$ & $7,54 \pm 0,52$ & $7,69 \pm 0,80^{*}$ & $7,80 \pm 0,56^{*}$ \\
\hline
\end{tabular}

У щурів дослідних груп, яким разом із важкими металами, згодовували препарати-антиоксиданти: селеніт натрію та метісевіт плюс, кількість лейкоцитів у їх крові вірогідно зростала вже починаючи з 14 доби досліду. Встановлено, що на 21 добу досліду кількість лейкоцитів у крові першої дослідної групи зросла на 35,3 \%, тоді як у другої дослідної групи даний показник зріс на 48,2 \% відносно контрольної групи щурів.

На 28 добу досліду кількість лейкоцитів у крові першої дослідної групи зростала, однак ще не доходила до початкових величин. Лише згодовування кормової добавки “Метісевіт плюс" сприяло підвищенню кількості лейкоцитів до фізіологічних величин.

Отже, селеніт натрію та кормова добавка "Метісевіт плюс" за розвитку хронічного свинцевокадмієвого токсикозу у крові щурів сприяє нормалізації морфологічних показників крові. Однак варто зауважити про кращу дію кормової добавки "Метісевіт плюс" на морфологічні показники крові щурів ніж застосування тваринам селеніту натрію.

\section{Висновки}

Свинцево-кадмієве навантаження у щурів супроводжувалося еритроцитопенією та лейкопенією, а також зниженням рівня гемоглобіну 3 одночасним зростанням середнього вмісту гемоглобіну в еритроциті.

Застосування селеніту натрію та кормової добавки “Метісевіт плюс" щурам за умов свинцево-кадмієвого навантаження сприяли підвищенню кількості еритро- цитів та рівня гемоглобіну, а також зниженню кількості лейкоцитів у їх крові.

Кращу нормалізуючу дію на морфологічні показники крові щурів за умов навантаження важкими металами проявляла кормова добавка "Метісевіт плюс" порівняно із селенітом натрію.

Перспективи подальших досліджень. У подальшому планується дослідити вплив кормової добавки "Метісевіт плюс" на стан системи антиоксидантного захисту організму щурів за умов навантаження важкими металами.

\section{References}

Al-Azemi, M., Omu, F. E., Kehinde, E. O., Anim, J. T., Oriowo, M. A., \& Omu, A. E. (2010). Lithium protects against toxic effects of cadmium in the rat testes. J. Assist. Reprod. Genet, 27(8), 469-476. doi: 10.1007/s10815-010-9426-3.

Ali, M. M., Murthy, R. C., \& Chandra, S. V. (1986). Developmental and longterm neurobehavioral toxicity of low-level in utero $\mathrm{Cd}$ exposure in rats. Neurobehavioral Toxicology and Teratology, 8(5), 463-468. https://www.ncbi.nlm.nih.gov/pubmed/3785508.

El-Shahat, A. E., Gabr, A., Meki, A. R., \& Mehana, E. S. (2009). Altered testicular morphology and oxidative stress induced by cadmium in experimental rats and protective effect of simultaneous green tea extract. Int. J. Morphol., 27(3), 757-764. doi: 10.4067/S071795022009000300020.

Gutyi, B., Ostapiuk, A., Kachmar, N., Stadnytska, O., Sobolev, O., Binkevych, V., Petryshak, R., Petryshak, 
O., Kulyaba, O., Naumyuk, A., Nedashkivsky, V., Nedashkivska, N., Magrelo, N., Golodyuk, I., Nazaruk, N., \& Binkevych, O. (2019). The effect of cadmium loading on protein synthesis function and functional state of laying hens' liver. Ukrainian Journal of Ecology, 9(3), 221-226. doi: 10.15421/2019_733.

Gutyj, B. V., Gufriy, D. F., Binkevych, V. Y., Vasiv, R. O., Demus, N. V., Leskiv, K. Y., Binkevych, O. M., \& Pavliv, O. V. (2018). Influence of cadmium loading on glutathione system of antioxidant protection of the bullocks'bodies. Scientific Messenger of Lviv National University of Veterinary Medicine and Biotechnologies, 20(92), 34-40. doi: 10.32718/nvlvet9207.

Hutyi, B. V. (2013). Vplyv Meveselu na pokaznyky neenzymnoi systemy antyoksydantnoho zakhystu orhanizmu buhaitsiv za umov kadmiievoho navantazhennia. Biolohiia tvaryn, 15(3), 16-21. Rezhym dostupu: http://nbuv.gov.ua/UJRN/bitv_2013_15_3_4

(in Ukrainian).

Hutyi, B. V. (2013). Vplyv meveselu na vmist vitaminiv A i E u krovi bychkiv za umov kadmiievoi intoksykatsii. Naukovyi visnyk Lvivskoho natsionalnoho universytetu veterynarnoi medytsyny ta biotekhnolohii im. Gzhytskoho, 15, 3(1), 78-82. Rezhym dostupu: http://nbuv.gov.ua/UJRN/nvlnu_2013_15_3(1)_18 (in Ukrainian).

Hutyi, B. V. (2013). Vplyv meveselu ta E-selenu na riven pokaznykiv ne fermentnoi systemy antyoksydantnoho zakhystu orhanizmu buhaitsiv pry kadmiievomu navantazhenni. Veterynarna medytsyna, 97, 419-421. Rezhym dostupu: http://nbuv.gov.ua/UJRN/vetmed 2013_97_172 (in Ukrainian).

Hutyi, B. V. (2015). Aktyvnist systemy antyoksydantnoho zakhystu orhanizmu bychkiv za hostroho kadmiievoho toksykozu. Naukovyi visnyk Lvivskoho natsionalnoho universytetu veterynarnoi medytsyny ta biotekhnolohii im. Gzhytskoho, 17, 1(1), 31-36. Rezhym dostupu: http://nbuv.gov.ua/UJRN/nvlnu 201517 1(1) 8 (in Ukrainian).

Hutyi, B. V., Slobodian, S. O., \& Kurylas, L. V. (2019). TU U 10.9 - 00492990-018:2019. Kormova dobavka "Metisevit plius" (in Ukrainian).

Kuras, L. D., \& Ersteniuk, H. M. (2019). Pokaznyky enerhetychnoho obminu $\mathrm{V}$ sertsevii tkanyni eksperymentalnykh tvaryn za umov vplyvu kadmii khlorydu. Medychna ta klinichna khimiia, 21(1), 2531. Rezhym dostupu: http://nbuv.gov.ua/UJRN/ Medkh_2019_21_1_6(in Ukrainian).

Lavryshyn, Y. Y., \& Gutyj, B. V. (2019). Protein synthesize function of bulls liver at experimental chronic cadmium toxicity. Scientific Messenger of Lviv National University of Veterinary Medicine and Biotechnologies. Series: Veterinary sciences, 21(94), 92-96. doi: 10.32718/nvlvet9417.

Lavryshyn, Y. Y., Gutyj, B. V., Palyadichuk, O. R., \& Vishchur, V. Y. (2018). Morphological blood indices of bulls in experimental chronic cadmium toxicosis. Scientific Messenger of Lviv National University of Veterinary Medicine and Biotechnologies, 20(88), 108-114. doi: 10.32718/nvlvet8820.
Lavryshyn, Y. Y., Gutyj, B. V., Paziuk, I. S., Levkivska, N. D., Romanovych, M. S., Drach, M. P., \& Lisnyak, O. I. (2019). The effect of cadmium loading on the activity of the enzyme link of the glutathione system of bull organism. Scientific Messenger of Lviv National University of Veterinary Medicine and Biotechnologies. Series: Veterinary sciences, 21(95), 107-111. doi: 10.32718/nvlvet9520.

Marushko, Yu. V., Tarynska, O. L., Olefir, T. I., \& Fus, S. V. (2010). Kadmii: nakopychennia ta vplyv na orhanizm dytyny. Medychna nauka Ukrainy, 3, 62-67. Rezhym dostupu: http://nbuv.gov.ua/UJRN/nvnmu 2010_3_12 (in Ukrainian).

Myslyva, T. M. (2013). Svynets i kadmii u hruntakh ahrolandshaftiv Zhytomyrskoho Polissia. Visnyk Sumskoho natsionalnoho ahrarnoho universytetu. Seriia: Ahronomiia i biolohiia, 3, 43-50. Rezhym dostupu: http://nbuv.gov.ua/UJRN/Vsna_agro_2013 3_13 (in Ukrainian).

Myslyva, T. M. (2013). Svynets i kadmii u hruntakh pryrodnykh i ahrolandshaftiv Zhytomyrskoho Polissia. Visnyk Zhytomyrskoho natsionalnoho ahroekolohichnoho universytetu, 1(1), 36-49. Rezhym dostupu: http://nbuv.gov.ua/UJRN/Vzhnau_2013_1(1)_8 (in Ukrainian).

Nazaruk, N., Gutyj, B., \& Hufriy, D. (2015). Influence of metifen and vitamix se on the activity of aminotransferases of bulls blood serum at cadmium nitrate loading. Scientific Messenger of LNU of Veterinary Medicine and Biotechnologies, 17(1), 121-126. Retrieved from https://nvlvet.com.ua/index.php/journal/article/ view/231.

Ostapyuk, A. Y., \& Gutyj, B. V. (2018). Influence of cadmium loading on morphological parameters of blood of the Laying Hens. Scientific Messenger of Lviv National University of Veterinary Medicine and Biotechnologies, 20(88), 48-52. doi: 10.32718/nvlvet8808.

Ostapyuk, A. Y., \& Gutyj, B. V. (2019). Influence of cadmium sulfate at different doses on the functional state of the liver of laying chicken. Scientific Messenger of Lviv National University of Veterinary Medicine and Biotechnologies. Series: Veterinary sciences, 21(94), 103-108. doi: 10.32718/nvlvet9419.

Petrynych, V. V., Vlasyk, L. I., \& Petrynych, O. A. (2017). Svynets: toksykolohichni, hihiienichni ta biolohichni aspekty. Klinichna ta eksperymentalna patolohiia, 16(2), 97-102. Rezhym dostupu: http://nbuv.gov.ua/UJRN/kep_2017_16_2_22 (in Ukrainian).

Rodríguez, E. M., Bigi, R., Medesani, D. A., Stella, V. S., Greco, L. S. L., Moreno, P. A. R., Monserrat, J. M., Pellerano, G. N., \& Ansaldo, M. (2001). Acute and chronic effects of cadmium on blood homeostasis of an estuarine crab, Chasmagnathus granulata, and the modifying effect of salinity. Brazilian Journal of Medical and Biological Research, 34(4), 509-518. https://www.ncbi.nlm.nih.gov/pubmed/11285463.

Sachko, R. G., Lesyk, Ja. V., Luchka, I. V., \& Nevostruyeva, I. V. (2016). Contents of heavy metals in food, organism and animal products in the Zacarpa- 
thian biogeochemical province. Scientific Messenger LNUVMBT named after S. Z. Gzhytskyj, 18, 3(71), 87-90. doi: 10.15421/nvlvet7120.

Salvatori, F., Talassi, CB, Salzgeber, S. A., Sipinosa, H. S., \& Bernardi, M. M. (2004). Embryotoxic and longterm effects of cadmium exposure during embryogenesis in rats. Neurotoxicology and Teratology, 26(5), 673-680. doi: 10.1016/j.ntt.2004.05.001.

Stepanchuk, V. V. (2014). Ontohenetychni osoblyvosti tsyrkadiannykh khronorytmiv vilnoradykalnoho homeostazu za umov svyntsevoho otruiennia. Klinichna ta eksperymentalna patolohiia, 13(2), 131-133. Rezhym dostupu: http://nbuv.gov.ua/UJRN/kep_2014 13_2_33 (in Ukrainian).

Uetani, M., Kobayashi, E., Suwazono, Y., Okubo, Y., Honda, R., Kido, T., \& Nogawa, K. (2005). Selenium, Cadmium, Zinc, Copper, and Iron Concentrations in Heart and Aorta of Patients Exposed to Environmental Cadmium. Bulletin of Environmental Contamination and Toxicology, 75(2), 246-250. doi: $10.1007 / \mathrm{s} 00128-005-0744-6$. 